\title{
The Public Metonym
}

\section{P. A. Cramer}

\section{Carnegie Mellon University}

\begin{abstract}
One of the central critiques of the bourgeois conception of public holds that, in its implicit claim to universality, it fails to account for the material particularities of social groups and for the variety of possible rationalities. Some theorists have aimed to solve this problem by describing particular publics and particular rationalities based on racial, ethnic, gender, or political identities. While particularist public models represent difference in protest of the totalizing and counterfactual valence of a bourgeois conceptualization of public, they fail to acknowledge that glossing difference is fundamental to the function of and the authorizing power of public, as it is marshalled by speakers. By analogizing Perelman and Olbrechts-Tyteca's universal audience with public, this paper (a) introduces the public metonym, a rhetorically productive counterfactual totality that glosses the material particularities of social groups, (b) critiques the particularist approach to the paradox of public, (c) introduces the resistance metonym as a rhetorically-minded alternative, and (d) clarifies distinctions among projects that claim to address a common object called public.
\end{abstract}

Résumé: Une des critiques majeures du concept bourgeois du publique affirme que, dans ses prétentions à l'universalité, il ne tient pas compte des particularités matérielles des groupes sociaux, ni des diverses possibilités de la raison. Quelques auteurs tentent de résoudre ce probleme en proposant des modèles différents du publique et de la rationalité; des concepts basés sur des critères raciaux, ethniques, sexuels, ou politiques. Quoique ces modèles plus particuliers offrent une alternative au concept bourgeois du publique, ils ne reconnaissent pas que le concept du publique employé par des intervenants visent justement à minimiser les différences entre les groupes sociaux.. En faisant une analogie avec le concept de l'audience universelle de Perelman et Olbrechts-Tyteca, j'introduis l'idée de la metonymie publique: une totalité illusoire, mais utile rhétoriquèment, qui passe au dessus de ces circonstances particulières des groupes sociaux. Je présente une critique des méthodes particularistes au paradoxe du publique; j'introduis le <la metonymie à résistance $>$ comme une alternative rhétorique, et je distingue nettement les divers projets qui élaborent une théorie de l'objet intellectuel commun que nous appelons un publique.

Keywords: public metonym, particularist publics, Habermas, Perelman, universal audience, public sphere, empiricism, normativity, models of rationality

\section{Introduction}

Habermas's work is widely acknowledged as a starting point in current theories of public, ${ }^{1}$ even among his opponents. His oft cited Structural Transformation of the Public Sphere ([1962] 1989) has been celebrated by Anglophone theorists, even while it suffers their withering critiques (Calhoun, 1992). One of the most com- 
mon complaints about Habermas's notion of public, and his rationalist notions of the ideal speech situation and universal pragmatics that grow out of it in his later work, is that it fails to account for the material particularities of social groups. Critics have complained that Habermas's theory is universalist, that it does violence to the rich variety of identities and positions that actually exist in societies. While Habermas (1982) has responded to this complaint by reminding us that his is a normative theory of modernity, the problem persists in the discussion and in his work, which is hardly free from empirical gestures. Among Habermas's critics, one of the commonest strategies for resolving the paradox of public-that is, the tension between public as a counterfactual totality and as a material and social fact-has been the invention of particularist publics. Beginning with Fraser (1993), who introduced "subaltern counterpublics" as a way of capturing difference within public while grounding it in an empirical attitude, a host of theorists have offered models of particularist publics.

Participants in the discussion tend to agree that public is conceptually complex and that its semantic variety presents theorists with a special challenge. The particularist public approach represents one way of drawing technical and theoretical distinctions within the complex, but this approach has significant limitations. In this paper I argue for another way of drawing these distinctions: I introduce the public metonym, a category with epistemological parallels to Perelman and Olbrechts-Tyteca's universal audience. Like the universal audience, the public metonym is a productive counterfactual totality that glosses the material particularities of social groups. One of the problems with particularist public models is that they ignore the fact that glossing difference is fundamental to the function of, to the authorizing power of the public metonym. This problem implies a broader one: particularist publics have little empirical basis in ordinary discourse while the public metonym has a broad one. While concepts of particularist publics aim to resolve the paradox of public, the public metonym accepts it and focuses on the glossing and totalizing function of public in discourse. As it does not aim to resolve the paradox, the public metonym implies a programmatic distinction between studies of speakers' efforts to marshal the public metonym, and sociological studies of agenda building and political will-formation, such as those suggested by Habermas's Between Facts and Norms (1996).

\section{Complexity}

The conceptual complexity of public has presented one of the most significant barriers to building a comprehensive theory. Habermas (1984, 1987a, 1987b, [1962] $1989,1990,1993,1996)$ has spent a career attempting to build a coherent and comprehensive account of it, among related concerns. Warner (2002) emphasizes the particular challenge that theorizing public presents. He suggests that the conceptual complexity of the phenomenon requires a "flexible method" of investigation (ibid., 16). He does not claim to present a coherent theory of public. In the 
introduction to his collection of essays, he writes, "I do not try to resolve all the generic or methodological unclarity that might result, let alone the conceptual and stylistic shifts from older essays to more recent ones" (ibid., 15). Indeed, any attempt to resolve methodological or conceptual shifts would entail developing a unified theory of public.

One approach to addressing the complexity of public is to ask what categories it resembles. Warner compares it to "rights, or nations, or markets" (ibid., 8). Yet all of these analogies contain significant limitations: Who has thought of him or herself as a member of "rights"? A representative of the "market"? What are the communicative conditions of "nation"? The difficulty of drawing an adequate analogy highlights the complexity of public. Warner's three analogies may fail in significant ways, but what holds the terms in common with public is their function as counterfactual totalities. Public distinguishes itself, however, as a totality that speakers use to identify themselves with a group (like nation), to authorize or ground a decision or a claim (like rights), and to describe a system of or venue distinguished by certain relations of exchange (like market). In addition to analogy as a way to address the complexity of public, Wamer attempts a semantic catalog of "public" and "private" as a way to organize the phenomenon, listing fifteen senses of the term that operate at a variety of levels of abstraction and in a variety of social contexts (ibid., 29-30). This catalog illustrates the broad range of meanings and uses of the term, and focuses our attention on the role of language in use in the debate over theories of public.

Whether we attempt to capture public by analogy or by definition, it is clear that this is a concept that operates at a high level of abstraction, is highly complex, and is widely distributed across a number of discursive contexts. This complexity presents an ongoing challenge to theorists of public, especially those who begin with the notion that public is a material and social category. In order to make progress in a theory of public, we need to take seriously the authorizing function of "public" in ordinary discourse, and to distinguish between "public" as a discursive category and "public" as a material/social category as it is used in theoretical discourse.

\section{The Paradox of Public}

Because public is a counterfactual totality, it necessarily glosses social and material difference. At the same time, speakers leverage public as if it is a material and social fact. This is the paradox of public. How can it both fail to account for material and social particularities, yet operate productively as if it resolves them? Some commentators have argued that this paradox is fundamentally ideological (Fraser, 1993; Negt and Kluge, 1993), that it represses and assimilates material and social particularities in order to deny representation in and access to the democratic franchise under the cover of inclusion. In response to Habermas's Structural Transformation of the Public Sphere ([1962] 1989), which first thematized 
the public paradox for theoretical interrogation, many theorists have been concerned with how to represent marginalized social groups within theories of public. Is there a relationship between public and the material particularities of social groups, and if so, what is the best way to describe it?

In many ways, this problem is endemic to the discussion. In The Structural Transformation of the Public Sphere, Habermas discusses the Janus-faced orientation of public. While he is explicit about the historical origins of the bourgeois public sphere under analysis, with its notable exclusions based on class, he suggests that the principle of publicity itself that emerges from this specific, and admittedly exclusionary, historical moment has value as an as-yet-unredeemed critical standard:

The identification of the public of "property owners" with that of "common human beings" could be accomplished all the more easily, as the social status of the bourgeois private persons in any event usually combined the characteristic attributes of ownership and education. The acceptance of the fiction of the one public, however, was facilitated above all by the fact that it actually had positive functions in the context of the political emancipation of civil society from mercantilist rule and from absolutistic regimentation in general (ibid., 56).

Note that Habermas acknowledges that the notion of a single and unified public body is a fiction; however, rather than concluding that this disqualifies the notion, he investigates the potential of the principle of publicity as a critical standard. His "fiction of the one public" occupies a conceptual status similar to Perelman and Olbrechts-Tyteca"s "universal audience" in that neither claims empirical accuracy but instead functions as an authorizing idealization and totality.

Later in Structural Transformation, Habermas defends the choice to take the principle of publicity seriously rather than disqualifying it:

Bourgeois culture was not mere ideology. The rational-critical debate of private people in the salons, clubs, and reading societies was not directly subject to the cycle of production and consumption, that is, to the dictates of life's necessities. Even in its merely literary form (of self-elucidation of the novel experiences of subjectivity) it possessed instead a "political" character in the Greek sense of being emancipated from the constraints of survival requirements. It was for these reasons alone the idea that later degenerated into mere ideology (namely: humanity) could develop at all (ibid., 160).

For the Habermas of Structural Transformation, the exemplary value of the emergent bourgeois public sphere of the eighteenth century lies in its relative insulation from "life's necessities" and its attendant priority on arguments among interlocutors as decisive. This focus is the one, of course, that he later develops in his communication theory (Habermas, 1984; 1987b). According to Habermas, the fact that the bourgeois public sphere of the eighteenth century rested on material exclusions that were contrary to its own principles ought not necessarily lead us to the conclusion that the principles themselves are without merit. 
Habermas begins by recognizing the authorizing power, the leverage of public. He makes this the original democratic moment. He imagines that members of the bourgeoisie gathered together in the role of public, as human beings, and that this cognitive shift was fundamental to democratic activity. At the same time, he recognizes that eighteenth-century Europe, as an historical moment, is a special context in which this notion of the public could develop as an authorizing necessity, given the shift from feudal to modern social, political, and economic life. He then goes on to imagine that this notion of public could have critical force in general, and he asks how it could be used to evaluate the material conditions of specific societies in historical context. With this move he goes from describing the origin and function of public as a counterfactual totality and asks how far the specific material conditions of a society diverge from the norms that can be divined from the totality. In view of this question he develops his "colonization" and "refeudalization" concepts, along with the notion of a "power-penetrated public sphere". He also takes on the social-scientific project of describing the social shape of the public sphere at a given historical moment. But how exactly does he shift from describing the origin and function of public as a counterfactual totality to fixing it as a set of norms and using it to evaluate material social conditions?

There is a theoretical and methodological tension embodied in the argument of Structural Transformation in its linking a historical project (describing the origin and function of public) with a deontological project (prescribing norms of publicity). Fraser (1993) and others have complained about Habermas' decision, in Structural Transformation, to turn the eighteenth century into a golden age and to take its model of public as universal and transcendent, applying it to the material and social conditions of later Western democracies. Habermas himself notes that both the prescriptive and descriptive are present in concepts of public, yet he has defended a kind of separation between these in his work since then. The Theory of Communicative Action (Habermas, 1984; 1987b) famously describes a rarefied communicative space in which power is bracketed, akin to his conceptualization of the public sphere. Although more sociological than historical, The Theory of Communicative Action develops a model to account for the continuous regeneration of the "lifeworld" in its tense but symbiotic relationship to the "system". For Habermas, the "system" is a reified outgrowth of moments or parts of the "lifeworld", which is itself dynamic and admits argumentative challenges to norms. In his theory, argumentation retains a special status in that power is bracketed in discourse so that the "ideal speech situation" may be presumed to operate. Still, the theory is not blind to material and social conditions. Habermas narrates the growth of modern economic and administrative forms of power by measuring its impact and relationship to the "lifeworld". Modern totalizing ideologies such as Nazism and Stalinism are, according to Habermas (1987b, 354), "modern manifestations of withdrawal and deprivation - that is to say, deficits inflicted upon the lifeworld by societal modernization". He terms the process by which this deprivation takes place, the "colonization of the lifeworld" (ibid., 355). 
In his communication theory, with its basis in the validity claims and communicative preconditions of universal pragmatics (Habermas, 1998), Habermas has restructured the tension from Structural Transformation, the tension between the descriptive and prescriptive projects. Rather than beginning with the historical and moving to the normative, as in Structural Transformation, he develops a normative model (universal pragmatics) that is grounded in a theory of human cognition and intersubjectivity. This approach is evidenced in his reliance on Lawrence Kohlberg from Justification and Application (Habermas, 1993) and in his use of Noam Chomsky in developing universal pragmatics (Habermas, 1998). In Justification and Application, Habermas asks how norms are developed and how they work in social practice. He remains committed to argumentative universalism as a precondition of discussions justifying norms, as the self-reflexive moment: "The general pragmatic presuppositions that must always be made by participants when they enter into argumentation, whether institutionalized or not, do not have the character of practical obligations at all but that of transcendental constraints" (Habermas 1993, 31). By making validity claims a human universal, Habermas both details the function of public and universalizes it. With his communication theory, Habermas explicitly grounds and justifies the deontological attitude that emerged in Structural Transformation.

For many theorists (Asen, 1999; Warner, 2002; Young, 1990), Habermas's communication theory only emphasizes and expands the most problematic aspects of Structural Transformation. Rather than resolving the problem, the theories of communication and morality provide a host of new and problematic, ideologically charged universals that exclude marginalized social groups under cover of inclusion. By universalizing the norms of communication, by locating them in human cognition and pragmatics, Habermas has championed a rarefied and exclusionary rationality, a model of rational deliberation that leaves no room for difference. These theorists propose alternative models of rationality, alternative conditions of argumentation.

By moving from a description of the origin and function of public to fixing it as a set of norms, Habermas (with many others in tow) has aimed to resolve the paradox of public, but instead he only sustains it. Theories of public are codifications of the public metonym. The key difference between theories of public and the leveraging of the public metonym in ordinary discourse is that theories explicitly thematize the features of the metonym in a self-reflexive fashion. In both cases, there lies a claim to universality. In ordinary discourse this is an implicit claim, and in theories of public it is an explicit claim or problem.

\section{The Public Metonym and the Universal Audience}

In the search for an analogue to public, Perelman and Olbrechts-Tyteca's (1971) universal audience lies closer to hand than market, rights, or nation. The universal audience, on the standard interpretation of their work, is a way of describing the 
rhetorical necessity and productivity of an addressee utterly abstracted from particular historical conditions. Although this interpretation is open to question, ${ }^{2}$ it receives support from passages such as the following:

Argumentation addressed to a universal audience must convince the reader that the reasons adduced are of a compelling character, that they are selfevident, and possess an absolute and timeless validity, independent of local or historical contingencies (ibid., 32).

Interpretative issues aside, more abstract formulations such as the one above help to bring out the similarity between the universal audience and the public metonym: both are productive counterfactual totalities that have little value in describing the material particularities of social groups. Their argumentative value lies precisely in the fact that they gloss particularity. An important difference between them is that the parent term of one ("audience") is more concrete and narrow than the parent term of the other ("public"): As some have emphasized (Habermas, [1962] 1989; Warner, 2002), public represents a wide semantic field in ordinary usage, and this presents theorists with a challenge. In order to adequately theorize public, we need to develop a more productive vocabulary that will carve up this wide semantic field and clarify theoretical categories of public from those of ordinary usage. Audience, on the other hand, has a narrower semantic field that tends to emphasize the material particularities of specific groups assembled to witness a performance. In order to theorize audience, rhetorical theorists, like Perelman and OlbrechtsTyteca, have had to extend its semantic field of ordinary usage to include a less concrete, more transcendent valence. In order to theorize public, we must select, focus, and specify from within its wide semantic field.

The public metonym, like the universal audience, is a counterfactual totality, and when speakers use "public", or one of its synonyms, they explicitly leverage the public metonym. The following is a characteristic instance of the use of the public metonym:

"From the public perspective, the Profile itself has become tainted," Yecke said. "It's too controversial. To say we're going to tweak the Profile yet again, I don't think that's what the public wants" (Draper, 2003).

In this case, Yecke, a Minneapolis school board member, leverages the public metonym in order to authorize her decision to scrap a particular educational standards profile for the state. Yecke, of course, cannot know what every one of her constituents thinks of the profile and cannot account for all of the possible individual or mass disenfranchisements from the democratic process surrounding it. She appeals to a counterfactual totality in the hopes that her listeners and readers will identify themselves with it-but she runs the risk that they will not.

Speakers use public as a metonym because it unifies, reduces, and instantiates what would otherwise be an unwieldy and unpersuasive description of a complex of commitments, identities, and differences. It fulfills the need for speakers to construct universal appeals and constituencies, and it can only do this by glossing the many more specific distinctions of identity that exist. Like the public metonym, the universal audience is not a matter of material fact: 
Naturally, the value of this unanimity depends on the number and quality of those expressing it. Its highest point is reached when there is agreement of the universal audience. This refers of course, in this case, not to an experimentally proven fact, but to a universality and unanimity imagined by the speaker, to the agreement of an audience which should be universal, since, for legitimate reasons, we need not take into consideration those which are not part of it. Philosophers always claim to be addressing such an audience, not because they hope to obtain the effective assent of all men-they know very well that only a small minority will ever read their works- but because they think that all who understand the reasons they give will have to accept their conclusions. The agreement of a universal audience is thus a matter, not of fact, but of right (Perelman and Olbrechts-Tyteca 1971, 31).

Public is a metonym exactly because it serves to unify, reduce, and instantiate. As in the case of "the heart" standing in for our complex, many-layered, sometimes conflicted feelings of love, the public metonym does this same discursive work in the world of civic action.

The parallel between public and audience is one that Warner (2002) explores. He stretches public across the epistemological variety of audiences, universal and particular, abstract and concrete, intended and real: "The public is a kind of social totality... A public can also be a second thing; a concrete audience, a crowd witnessing itself in visible space, as with a theatrical public" (ibid., 65). This presents a formal problem: If public and audience are isomorphic, why do we need both categories? In part, the answer to this question is that public is a normative and authorizing category while audience (with the exception of the special case of the universal audience) is not. This is why Perelman and Olbrechts-Tyteca must modify audience in order to give it authorizing power. Warner overextends his analogy. He writes, metadiscursively, "This essay has a public. If you are reading (or hearing) this, you are part of its public" (ibid.). If I am reading his essay, I am certainly part of his actual audience (whether or not I am part of his intended audience). But Warner's easy substitution of public for audience tends to flatten important distinctions between the categories. Because public emphasizes universality and openness along with authorizing power (Habermas, [1962] 1989; Warner, 2002) public has much more in common with the universal audience than it has with other, more particular audiences, like the individual reader of Warner's essay. In addition, public is part of the grounds of an argument, explicitly thematized in discourse and playing an authorizing role, while actual audiences are addressees. Whether I am part of the public, in the case of Warner's essay, depends, in part, on Warner's aims and my intentions. Is he appealing to the public metonym? Am I persuaded by that appeal? Perelman and Olbrechts-Tyteca $(1971,31)$ suggest that philosophers always claim to be addressing the universal audience, but this is different in the case of the public metonym. Naturally, political figures are those who always claim to be addressing the public metonym. Does Warner have reason to address the universal audience? To lobby the authorizing function of the public metonym? 


\section{Particularist Publics}

If public is a metonym, like the universal audience, if it is a counterfactual totality that glosses a complex of historical particularities, can particular publics exist? Many theorists have developed models that feature particularist publics (Asen, 1999; Asen and Brouwer, 2001; Fraser, 1993; Negt and Kluge, 1993; Warner, 2002; Young, 1990). Generally, these models respond to widespread concerns about Habermas' emphasis on universality and rationality in his theory of the public sphere and in his communication theory. They argue that Habermas' theory fails to account for the material particularities of social groups and for the variety of possible rationalities. They solve this problem by describing particular publics and particular rationalities based on racial, ethnic, gender, or political identities.

However, these theories of particularist publics ignore the fact that glossing difference is fundamental to the function and authorizing power of the public metonym. No speaker who wishes to enjoy an identification with fundamental or general interests has a motive to thematize difference. In addition, particularist publics defy empirical facts of language in use: A "female public", "African-American public", "environmentalist public", or other such marked publics are, at best, theoretical possibilities. These constructions are not widely used in the language, if at all. Particularist publics are publics without history. They are non-empirical, negative categories invented to call attention to the quashing of difference by the public metonym, but they don't produce a solution. They are at best resistance categories, presented with an attitude of advocacy toward broadening the democratic franchise of specific societies, and at worst performative, presented with the attitude of Derridian play, intended to assert, but not account for, difference. They don't so much produce a viable alternative to the public metonym as they protest its existence and function.

Perhaps the only particularist publics that are widely referenced in ordinary language are corporate publics. We routinely speak of the "fashion-buying public", "car-buying public", or other such market-oriented categories. This kind of appropriation of civic categories by corporate interests is evidence for precisely the kind of privatization that Habermas ([1962] 1989), and many of the other theorists of public resist. Readings (1996) has noted the ease with which the categories of identity politics, often championed as boundaries of resistance, are appropriated by marketing interests. Asen and Brower (2001) and Young (1997) point out limitations of identity constructions as a basis for particularist publics. The problems of "authenticity" and the problems of transcendent subjectivity in identity politics are well documented (Hall, 1991; Readings, 1996; Spivak and Gunew, 1993; Taylor, 1992). Particularist publics based on identity rest on our ability unproblematically to identify and authorize individuals who represent cultural, discursive, ethnic, gender, and class categories. It is no wonder that corporate interests have found it so easy to transform these categories into "target markets", selling identity to consumers. 
Racial, ethnic, or gender identity is not the only aspect of pluralist publics. The notion of counterpublics, first characterized by Fraser (1993) as "subaltern counterpublics", represents an effort to capture both identity and political exclusions. Asen and Brower describe counterpublics in this way:

For counterpublics derive their 'counter' status in significant respect from varying degrees of exclusions from prominent channels of political discourse and a corresponding lack of political power. The power frequently denied counterpublics consists not only in the capacity to induce or compel actions from others, but power in the Arendtian (1958) sense of that which arises when citizens act jointly. However, exclusion is neither fixed nor total. Sometimes, ostensibly inaccessible means and venues provide opportunities for counterpublic and state interaction. Other times, alternative modes and sites engender such interactions (Asen and Brower, 2001, 2-3).

In this formulation, counterpublics emphasize exclusion from political power and from the democratic franchise, and they focus on categories of social structure. Still, they thematize identity politics: "Counterpublic spheres voice oppositional needs and values not by appealing to the universality of the bourgeois public sphere but by affirming specificity of race, gender, sexuality, ethnicity, or some other axis of difference" ( ibid., 7). Sometimes a counterpublic seems synonymous with existing identity categories. Sometimes it is a purely critical and performative category in relation to a given society's dominant channels of political discourse.

Part of the problem in grasping just what is meant by counterpublics lies in an explicit de-emphasis of methodological concerns by its advocates. Some who have championed counterpublics (Warner, 2002; Young, 1990) make no secret of their trade-off between advocacy and coherence. Warner (2002) suggests that the conceptual complexity of public requires a "flexible method" of investigation (ibid., 16). He does not claim to present a coherent theory of public. In the introduction to his collection of essays, he writes, "I do not try to resolve all the generic or methodological unclarity that might result, let alone the conceptual and stylistic shifts from older essays to more recent ones" (ibid., 15). Young is also quite explicit about her priorities:

Methodological and epistemological issues do arise in the course of this study, but 1 treat them always as interruptions of the substantive normative and social issues at hand. I do not regard any of the theoretical approaches which I take up as a totality that must be accepted or rejecting in its entirety. Each provides useful tools for the analyses and arguments 1 wish to make (Young, 1990, 8).

These comments support the conclusion that pluralist publics are performative categories that assert, but typically do not account for, difference within the civic imaginary. They do not so much produce a viable alternative to the public metonym as they stand in protest to its existence and function.

The particularist publics program begins by complaining that Habermas's theory fails to account for the material particularities of social groups. Habermas (1990) has defended his emphasis on universality and rationality by positioning his work 
in relation to moral theory and insisting on the need for counterfactuals; in effect he claims that to demand an account for material particularities is to misunderstand the purpose of his work. The particularist publics program, positioned as a therapeutic call for empirical grounding of theories of public ("actually existing democracy" as Fraser calls it), ultimately relies on counterfactuals as well: identity categories that gloss difference and categories of public that defy empirical facts of language in use.

\section{The Public Metonym and the Resistance Metonym}

While the initial justification for particularist publics is empirical (Fraser, 1993), they seem to stand instead as categories of advocacy, totalities that would be useful for organizing groups toward social action if they did exist, or as hypotheticals, as they exist in theories that assert the possibility of difference in protest of the public metonym. While the negative program emphasizes this hypothetical function, perhaps a positive program could emphasize the social-action function: How do we construct totalities in order to synthesize and organize groups toward social action? This is one of the primary questions driving Laclau and Mouffe (1985) toward their theory of hegemony. They rehabilitate Gramsci's notion of hegemony, the tendency of bourgeois political structures to assimilate and accommodate difference into itself, as a way of describing and prescribing the construction of totalities in order to synthesize and organize otherwise divergent groups toward social action. They explicitly advocate for marginalized social groups, they acknowledge that these groups lack access to dominant channels of political discourse, and they appreciate the necessity of group imaginaries-hegemony in their terminology -in synthesizing and organizing them for political action. At the same time, Laclau and Mouffe are theorists of the resistance metonym rather than the public metonym in that they focus on inventing totalities that are necessary for political will-formation but that do not claim universality.

The resistance metonym functions as a totality that glosses difference for the purpose of solidarity toward political action. Notice the difference in purpose between the public metonym and the resistance metonym; The public metonym is universal, in that it makes a claim to represent all members of a polity, and the resistance metonym is distinctive in that it makes a claim to represent all members of a particular grievance group. Both, of course, operate as metonyms, glossing the differences among members, yet they operate at different levels of abstraction. Some of the strong claims for particularist publics attempt to escape the basic metonymic function, yet this presents a problem that is less a matter of politics and more a matter of theoretical coherence: If difference is our first principle, then what keeps particularist publics from being so highly differentiated that each person could claim to constitute a public? The resistance metonym provides a way to talk about group imaginaries that thematize broad political difference without the burden of accounting for all of the material particularities of its constituents. 
Particularist publics highlight, but do not escape, the paradox of public because they maintain moral-universalist terminology while claiming to thematize difference. While there are obvious normative and political benefits to laying claim to "public", especially in projects that position themselves as theories of democracy, particularist publics want to have it both ways. As a theory of conflict and resistance, Laclau and Mouffe's approach avoids the paradox by making no pretense to democratic universality. They stay focused on the material and rhetorical challenges of organizing grievance groups for social action. And by thematizing the power of discourse in inventing social totalities, they respect the necessary and mediating function of language.

\section{The Public Metonym and Agenda Building}

In this discussion, I have aimed to distinguish between two projects that seem often to be confused by theorists of public: an investigation of the public metonym and an investigation of the material particularities of social groups. Laclau and Mouffe's project presents an interesting attempt to account for material particularities while attending to the discursive function of the resistance metonym. Yet they do not claim to offer a theory of public, despite the fact that they must assume certain qualities of social openness. Moreover, they do not make explicit claims about universal discursive norms or universal group membership, claims implicit in the public metonym.

Habermas has, in many ways, encouraged a confusion of these two projects insofar as the paradox of public runs through his work. He has taken a famously interdisciplinary approach consistent with critical theory, sometimes emphasizing history (Habermas, [1962] 1989), sometimes sociology (Habermas, 1987b), sometimes communication and linguistics (Habermas, 1984; 1998), and sometimes moral philosophy (Habermas, 1990; 1993). His most recent work (Habermas, 1993, 1996) explicitly articulates the role and maintenance of norms and the relationship between these norms and the material particularities of societies. Between Facts and Norms (Habermas, 1996) explores law as the institutional venue for the codification of norms, a venue in which the argumentative and legal procedures meet:

This intersection of two quite different "procedures"- legal and argumentative-shows that the universe of law can open itself from the inside, as it were, to argumentation processes through which pragmatic, ethical, and moral reasons find their way into the language of law without either inhibiting the argumentation game or rupturing the legal code (ibid., 178).

Between Facts and Norms is Habermas's effort to describe how existing social and institutional channels admit public opinion and allow for or encourage political will-formation. In this project, he maintains his commitments to the discourse principle, to argumentative preconditions, and to the functional separation of informal public space and formally organized legislative and judicial forums. This is to say that while he highlights law as the point of contact for informal and formal 
opinion-formation, he maintains his long-held normative priorities based in universal pragmatics and discourse ethics. In this he remains in conflict with theorists who promote models of particularist publics, that is, theorists who argue for alternative rationalities emphasizing gender (Young, 1990; 2000), performance and play (Warner, 2002), or "thin norms" (Asen, 1999; Walzer, 2001).

In a certain sense, Habermas has his own notion of particularist publics, but his differs notably from others: While others emphasize categories of identity and alternative rationalities, Habermas' is primarily sociological and intersubjective. In Between Facts and Norms Habermas discusses "autonomous public spheres", and rejects a notion of public as a "macrosocial subject", public as a collective actor. This is consistent with his ongoing emphasis on intersubjectivity as a salve for the transcendentalism of the philosophy of the subject. Autonomous public spheres are valuable for Habermas because they allow him to socialize his conception of public deliberation into his model of agenda building. Autonomous public spheres are the most informal social structures in Between Facts and Norms, and Habermas links them with channels of political discourse through voluntary associations. He writes:

Resonant and autonomous public spheres of this sort must in turn be anchored in the voluntary associations of civil society and embedded in liberal patterns of political culture and socialization; in a word, they depend on a rationalized lifeworld that meets them halfway. The development of such lifeworld structures can certainly be stimulated, but for the most part they elude legal regulation, administrative control, or political steering (Habermas, 1996, 358-359).

Note two things about autonomous public spheres. The pluralization of "spheres" suggests a variety of social venues or spaces and "autonomous" suggests a relative freedom from political pressures. About the autonomy of public spheres, Habermas writes:

These arenas must certainly be constitutionally protected in view of the space they are supposed to make available for free-floating opinions, validity claims, and considered judgments. On the whole, though, they cannot be organized like corporate bodies (ibid,, 171).

With his focus on agenda building, that is, on asking how political will-formation works and what role "public" may play, Habermas aims to locate his normative theory in social space. He adjusts his notion of public to allow for the possibility of a variety of social containers while he maintains the priority he ascribes to an intersubjective rationality within those spaces:

Deliberative politics acquires its legitimating force from the discursive structure of an opinion- and will-formation that can fulfill its socially integrative function only because citizens expect its results to have a reasonable quality. Hence the discursive level of public debates constitutes the most important variable (ibid., 304).

With his invention of autonomous public spheres, Habermas has contributed to the particularist publics approach. Although he avoids the problems of identity 
politics by distancing himself from its transcendent subjectivity, he does not escape the paradox of public. As with other particularist publics, Habermas's model treats his autonomous public spheres more as social facts than as functions of the public metonym. Unlike the other particularist versions, however, his employment of public pertains primarily to agenda building in deliberative democracy rather than to resistance and protest. Still, similar problems afflict his model to the extent that it does not adequately distinguish sociological and rhetorical employments of public.

\section{Conclusion}

One of Habermas' most significant contributions has come through his effort to divine from the public metonym both a set of deliberative norms and a critical analysis of social institutions. In this he has significantly shaped the discussion and theories of deliberative democracy and has opened up rich research questions investigating deliberative norms, social institutions, and their relationship. Although the historical development of the public metonym was his initial motivation (Habermas, [1962] 1989), his later work illustrates the methodological value of specifying and refining research questions toward particular philosophical, moral, and social problems that are implied by the semantic complex of the public metonym. By emphasizing agenda building and political will-formation in Between Facts and Norms, Habermas offers yet another promising, and perhaps more finely grained, way to examine democratic practice. He continues to lead the way in describing the scope of the problem and in suggesting fruitful approaches to public and its related concerns. Although Habermas's celebrated methodological and theoretical eclecticism is one of his strengths, it may have encouraged a certain conflation of issues and problems among theorists of public.

Theories of public are codifications of the public metonym. The key difference between theories of public and the leveraging of the public metonym in ordinary discourse is that theories explicitly thematize the features of the metonym. Still, theories that take public to be a material and social totality, regardless of the care with which they are constructed, risk tautology. We need to distinguish between three projects: the project that asks who has been excluded from the democratic franchise, the project that asks what should be the deliberative norms of democratic societies, and the project that asks how the public metonym operates as a rhetorical resource.

Each of these approaches claims to theorize public, yet each takes a different object of study. This confusion is a function of the conceptual complexity of public and is a barrier to progress in theorizing public. When we treat it as a social fact, public is a distinct mass of individuals who could, in principle, be identified, polled, and/or catalogued. When we treat it as a normative counterfactual, public is a set of pragmatic qualities that inheres between subjects. When we treat it as a metonym, public is a specific speaker's representation of a distinct mass of indi- 
viduals and set of pragmatic qualities, offered as if it were given and universal. While the first approach examines societies and the second divines norms, the third examines the discourse of speakers.

Distinguishing the public metonym from these other approaches clarifies the role that discourse plays in theories of public. It focuses attention on the ways that speakers and societies, through discourse, construct concepts of universal civic inclusion. Future research on the public metonym would involve empirical investigation of texts in which the public metonym is leveraged. This empirical work would allow researchers to make claims about the rhetorically productive civic totalities of a given society. Work on the public metonym both complements and challenges sociological investigations and normative models. By focusing on public as a discursive totality leveraged in ordinary discourse, it complements the other two projects by revealing an under-explored rhetorical component. At the same time, it challenges them by revealing their tendency to downplay or ignore the constructive and persuasive role of discourse.

\section{Notes}

'Throughout this paper, I refer to public in a novel way, using it without a preceding article. This usage is consistent with and made necessary by my argument: As I argue in the next section, the conceptual complexity of public has been one of the most significant barriers to building a comprehensive theory, and this complexity is reflected in and based on the use of public in ordinary discourse. This paper invents both the article-free "public" and the "public metonym" in order to escape the traps of ordinary usage. In order to summarize the various theoretical positions on public, some of which emphasize public as a quality or norm ("publicity" or "publicness") and some of which emphasize public as a body ("the public" "a public"), I needed a novel usage that could provide maximum semantic coverage. Although later in this paper I argue for more careful distinctions between projects that treat public as a social fact, as a set of norms, or as a discursive totality, I must acknowledge that theorists have tended to treat all of these kinds of projects as part of the same discussion. The article-free "public" allows me to acknowledge this status quo without implicitly taking a position through my usage. The other novel term introduced here, the "public metonym", then, is my more explicit contribution to the discussion.

${ }^{2}$ Perelman and Olbrechts-Tyteca's universal audience has enjoyed careful and nuanced analysis by argumentation theorists Tindale (1999) and Crosswhite (1996). They have used Perelman and Olbrechts-Tyteca to reinterpret some of the fundamental concerns of informal logic, e.g. fallacies, and have used the rhetorical perspective of Perelman and Olbrechts-Tyteca as a way to challenge and expand argumentation theory. 


\section{References}

Asen, R. (1999). Toward a Normative Conception of Difference in Public Deliberation. Argumentation and Advocacy, 35, 115.

Asen, R., and D. C. Brouwer. (2001). Counterpublics and the State. Albany: SUNY Press.

Calhoun, C. J. (1992). Habermas and the Public Sphere. Cambridge, MA: MIT Press.

Crosswhite, J. (1996). The Rhetoric of Reason. Madison: University of Wisconsin Press.

Draper, N. (2003). Fast Track to Learning Standards is Slowed: Comments Prompt Yecke to Consider Revising Drafts. Minneapolis Star Tribune. March 29, 2003.

Fraser, N. (1993). Rethinking the Public Sphere: A Contribution to the Critique of Actually Existing Democracy. In R. Bruce (Ed.), The Phantom Public Sphere (pp. 1-32). Minneapolis: University of Minnesota Press.

Habermas, J. (1982). A Reply to My Critics. In B. T. John and H. David (Eds.), Habermas: Critical Debates (pp. 219-283). Cambridge, MA: MIT Press.

Habermas, J. (1984). The Theory of Communicative Action (T. McCarthy, Trans. Vol. 1). Boston: Beacon.

Habermas, J. (1987a). The Philosophical Discourse of Modernity (F. Lawrence, Trans.): Cambridge, MA: MIT Press.

Habermas, J. (1987b). The Theory of Communicative Action (T. McCarthy, Trans. Vol. 2). Boston: Beacon.

Habermas, J. ([1962] 1989). The Structural Transformation of the Public Sphere (T. B. w. F. Lawrence, Trans.). Cambridge, MA: MIT Press. 1962 German edition: Strukturwandel der Offentlichkeit. Berlin: Luchterhand.

Habermas, J. (1990). Moral Consciousness and Communicative Action (C. Lenhardt and S. W. Nicholsen, Trans.). Cambridge, MA: MIT Press.

Habermas, J. (1993). Justification and Application (C. Cronin, Trans.). Cambridge, MA: MIT Press.

Habermas, J. (1996). Between Facts and Norms (W. Rehg, Trans.). Cambridge, Mass.: MIT Press.

Habermas, J. (1998). On the Pragmatics of Communication (M. Cook, Ed.). Cambridge, MA: MIT Press.

Hall, S. (1991). The Local and the Global: Globalization and Ethnicity. In A. D. Anthony (Ed.), Culture, Globalization, and the World-System (pp. 19-39). Basingstoke; Macmillan.

Laclau, E., and C. Mouffe. (1985). Hegemony and Socialist Strategy. New York: Verso. Negt, O., and A. Kluge. (1993). Public Sphere and Experience (J. D. Peter Labanyi, and A. Oksiloff, Trans.). Minneapolis: University of Minnesota Press.

Perelman, C., and L. Olbrechts-Tyteca. (1971). The New Rhetoric (J. Wilkinson and P. Weaver, Trans.). Notre Dame: University of Notre Dame Press.

Readings, B. (1996). The University in Ruins. Cambridge, MA: Harvard University Press. Spivak, G. C., and S. Gunew. (1993). Questions of Multiculturalism. In D. Simon (Ed.), The Cultural Studies Reader (pp. 193-202). London: Routledge. 
Taylor, C. (1992). Multiculturalism and the Politics of Recognition (A. Gutmann, Ed.). Princeton: Princeton University Press.

Tindale, C. W. (1999). Acts of Arguing. Albany: SUNY Press.

Walzer, M. (2001). Thick and Thin. Notre Dame: University of Notre Dame Press.

Warner, M. (2002). Publics and Counterpublics. New York; Cambridge, MA: Zone Books; Distributed by MIT Press.

Young, I. M. (1990). Justice and the Politics of Difference. Princeton: Princeton University Press.

Young, I. M. (1997). Intersecting Voices. Princeton: Princeton University Press.

Young, I. M. (2000). Inclusion and Democracy. Oxford: Oxford University Press.

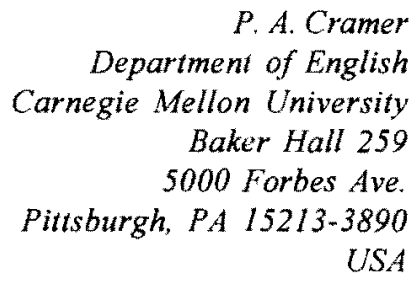

email: pcramer@andrew.cmu.edu 